các yếu tố nguy cơ cao có giá trị tiên lượng về di căn hạch sẽ giúp xác định được chiến lược điều trị phù hợp.

\section{KẾT LUÂN}

Vi ung thư tuyến giáp thể nhú thường được tình cờ phát hiện qua khám sức khỏe định kỳ, chủ yễu gặp ở nữ giới dưới 45 tuổi. Tỉ lệ di căn hạch của nhóm bệnh nhân này là $70,7 \%$. Tỉ lệ chọc hút tế bào bẳng kim nhỏ chẩn đoán ác tính với u tuyến giáp chiếm $77 \%$, các trường hợp âm tính giả được làm sinh thiết tức thì trong mổ cho kết quả dương tính.

Di căn hạch cổ khoang trung tâm thường gặp ở nam giới trẻ tuổi $(<45)$, ung thư 2 thùy, u phá võ vỏ xâm lấn ngoài tuyến, tổn thương đa ổ và kích thước u trên $0,5 \mathrm{~cm}$.

\section{TÀI LIÊU THAM KHẢO}

1. C.W.E Hedinger, L.H Son (1988). WHO histologic typing of thyroid tumors. ApringerVerlag, New York.

2. D Karakoc, A Ozdemir (2010). Lymph Node Surgery in Papillary Thyroid Carcinoma. Int Surg, 95, $142-146$.
3. Lee Kwan Ju, Cho Yun Jung, Kim Say Jun, et al. (2011). Analysis of the clinicopathologic features of papillary thyroid microcarcinoma based on 7-mm tumor size. World journal of surgery, 35(2), 318-323.

4. Hwang Harry S, Orloff Lisa A (2011). Efficacy of preoperative neck ultrasound in the detection of cervical lymph node metastasis from thyroid cancer. The Laryngoscope, 121(3), 487-491.

5. Hoàng Huy Hừng (2016). Đánh giá di căn hạch của ung thư biểu mô tuyến giáp, Trường Đại học $Y$ Hà Nội, Hà Nội.

6. Lu Zhong-Zhi, Zhang Yan, Wei Song-Feng, et al. (2015). Outcome of papillary thyroid microcarcinoma: Study of 1,990 cases. Molecular and clinical oncology, 3(3), 672-676.

7. Roti Elio, Rossi Roberta, Trasforini Giorgio, et al. (2006). Clinical and histological characteristics of papillary thyroid microcarcinoma: results of a retrospective study in 243 patients. The Journal of Clinical Endocrinology \& Metabolism, 91(6), 2171-2178.

8. Lê Văn Quảng, Ngô Quốc Duy, Mai Thế Vương, và công sư (2019). Đánh giá các yếu tố ảnh hưởng tới tỉnh trạng di căn hach nhóm 6 ở bệnh nhân vi ung thư biểu mô tuyển giáp thể nhú giai đoạn cNO. Tạp chí Ung thư học Việt Nam, Số 1 - 2019.

\title{
KẾT QUẢ PHẪU THUÂT NộI SOI LỒNG NGỰC MộT LỖ ĐIỀU TRI UNG THƯ PHỔI KHÔNG TẾ BÀO NHỎ GIAI ĐOAN SỚM TẠI BỆNH VIỆN HỮU NGHI VIỆT ĐỨC
}

\section{TÓM TẮT}

Đắt vấn đề: Ung thư phổi là một trong những ung thư thường gặp nhất và là nguyển nhân gây tử vong hàng đâu trển thế giới. Phâuu thuật là phương pháp điêu trị được lựa chọn đầu tiên đối với ung thư phổi không tế bào nhỏ giai đoạn sớm (I, II) trong đó có phẫu thuật nội soi một lỗ. Tại bệnh viện hữu nghị Việt Đức đã triển khai thường qui phẫu thuâtt này và có những tổng kết bước đầu nhưng vẫn cần có tổng kết và đánh giá kết quả một cách tổng quan của phương pháp. Phương pháp: Nghiên cứu mô tả, hồi cứu 37 bệnh nhân ung thư phổi không tế bào nhỏ giai đoạn sớm được điều trị bằng phẫu thuật nội soi lồng ngực môt lỗ từ tháng 01/2016 tới $06 / 2021$ về các thộng số trước, trong và sau mổ cùng kết quả giải phẫu bệnh.... Kết quả: Bao gồm 21 nam và 16 nữ.

${ }^{1}$ Đai hoc Y Hà Nọi

${ }^{2}$ Bệnh viện Hữu nghi Việt Đức

${ }^{3}$ Bệnh viện đa khoa tỉnh Yên Bái

Chịu trách nhiệm chính: Phạm Hữu Lư

Email: phamhuulu@hmu.edu.vn

Ngày nhận bài: 12.7.2021

Ngày phản biên khoa hoc: 6.9.2021

Ngày duyệt bài: 13.9.2021

\section{Phạm Hữu Lư ${ }^{1,2}$, Nguyễn Mạnh Hiệp ${ }^{3}$}

Tuổi trung bình 59,62 $\pm 8,79$ (34 - 76). Kích thước khối u trung bình 2,97 cm, trong đó kích thước nhỏ nhất $1 \mathrm{~cm}$; lớn nhất $5 \mathrm{~cm}$. Thời gian phẫu thuât $150 \pm$ 22,58 phút (90-195). Thời gian rút dấn lưu màng phổi trung bình $5,59 \pm 1,46$ ngày (3- 9 ). Số ngày nằm viện trung bình 7,54 $\pm 1,86$ ngày (4-12). Không có tử vong, tai biến và biến chứng nặng trong và sau mổ. Kết quả giải phẫu bệnh sau mổ: 34 ung thư biểu mô tuyến và 2 ung thư biểu mô vảy, 1 ung thư khác. Giai đoạn ung thư: 18 trường hợp giai đoạn I, 19 trường hợp giai đoạn II. Kết luận: Điều trị ung thư phổi không tế bào nhỏ giai đoạn sớm bằng phẫu thuật nội soi lồng ngực một lố là một phương pháp an toàn, khả thi và có nhiều ưu điểm.

Tư khóa: Ung thư phổi không tế bào nhỏ, phẫu thuật nội soi lồng ngực một lỗ

\section{SUMMARY}

\section{RESULTS OF UNIPORTAL VIDEO-ASSISTED THORACOSCOPIC SURGERY FOR EARLY- STAGE NON-SMALL CELL LUNG CANCER AT VIET DUC UNIVERSITY HOSPITAL}

Background: Lung cancer is one of the most common cancers and the leading cause of death worldwide. Surgery is the treatment of first choice for early stage (I, II) non-small cell lung cancer including 
uniportal video - assisted thoracoscopic surgery. At Viet Duc University Hospital, this surgery routine has been carried out and there are initial summaries, but it is still necessary to summarize and evaluate the results in an overview of the method. Methods: A descriptive, retrospective study of 37 patients with early-stage non-small cell lung cancer treated by uniportal video-assisted thoracoscopic surgery from January 2016 to June 2021 on pre-operative, inoperative and post-operative parameters, pathological results.... Results: Includes 21 men and 16 women. The mean age was 59,62 $\pm 8,79$ (34 - 76). The average tumor size is $2.97 \mathrm{~cm}$, of which the smallest is $1 \mathrm{~cm} ; 5 \mathrm{~cm}$ maximum. Surgery time $150,00 \pm 22,58$ minutes (90-195). The average time of chest drain was $5,59 \pm 1,46$ days (3-9). The average number of hospital days was 7,54 $\pm 1,86$ days (4-12). There were no deaths, accident and serious complications during and after surgery. Postoperative pathological results: 34 adenocarcinomas and 2 squamous carcinomas, 1 other cancers. Cancer stage: 18 cases of stage I, 19 cases of stage II. Conclusion: Treatment of early non-small cell lung cancer by uniportal video-assited thoracoscopic surgery is a safe, feasible and advantageous method.

Keywords; non-small cell lung cancer, uniportal video-assisted thoracoscopic surgery

\section{I. ĐĂT VẤN ĐỀ}

Ung thư phổi là một trong những ung thư thường gặp nhất và là nguyên nhân gây tử vong hàng đầu trên thế giới, đây là bệnh ung thư thường gă̆p thứ hai ở nam giới và là bệnh ung thư thường găpp đứng thứ ba ở nữ giới. Ớ Việt Nam, con số này là $23.667 \mathrm{ca}$ ung thư phổi mới phát hiện và 20.170 người tử vong mỗi năm [1]. Theo phân loại của tổ chức $Y$ tế thế giới, ung thư phổi được chia làm 2 nhóm chính: Ung thư phổi không tế bào nhỏ và ung thư phổi tế bào nhỏ, trong đó ung thư phổi không tế bào nhỏ chiếm 80- 85\%.

Điều trị ung thư phổi không tế bào nhỏ là đa mô thức, bao gồm phẫu thuẫ̂t, hóa chất, xạ trị, điều trị đích... Trong đó, phẫu thuật là phương pháp điều trị được lựa chọn đầu tiên đối với giai đoạn sớm (I, II) với khoảng 25-30\% bệnh nhân có chỉ định phẫu thuật [2] .

Hiện nay, phẫu thuật điều trị ung thư phổi ngày càng phát triển, ngoài mổ mở kinh điển thì từ những năm 90 thế kỷ trước nhiều tác giả đã ứng dụng phẫu thuật nội soi lồng ngực trong điều trị bệnh lý này và đã có nhiều bài báo đã được công bố. Phẫu thuật nội soi lồng ngực một lỗ được mô tả đâu tiên bởi Rocco và cộng sự (Ý) vào năm 2000 [3], sau đó được chấp nhận và thực hành rộng rãi bởi các phẫu thuật viên lồng ngực trên thế giới [4], [5].

Những năm gân đây phẫu thuật nội soi lồng ngực một lỗ đã được thực hành tại một số trung tâm phẫu thuật lồng ngực trong cả nước mang lại kết quả bước đầu. Trong phẫu thuật điều trị ung thư phổi không tế bào nhỏ giai đoạn sớm tại trung tâm tim mạch và lồng ngực - bệnh viện hữu nghị Việt Đức đã tiến hành thường qui phương pháp này với những tổng kết bước đâu nhưng vân cần có tổng kết và đánh giá kết quả một cách tổng quan của phương pháp.

\section{II. ĐỐI TƯợNG VÀ PHƯƠNG PHÁP NGHIÊN CỨU}

2.1. Đối tượng. Bệnh nhân ung thư phổi tế bào không nhỏ giai đoạn I, II được điều trị bằng phẫu thuật nội soi lồng ngực một lỗ tại Trung tâm Tim mạch- Lồng ngực bệnh viện Hữu nghị Việt Đức, từ 1/2016 đến 10/2021.

\section{* Tiêu chuẩn lựa chọn bệnh nhân}

- Không phân biệt tuổi, giới

- Bệnh nhân được chẩn đoán ung thư phổi không tế bào nhỏ bằng lâm sàng, cận lâm sàng cùng kết quả giải phẫu bệnh trước mổ hoặc sinh thiêt tức thì trong mổ.

- Được điều trị cắt thùy phổi, vét hạch bằng phương pháp phấu thuật nội soi lồng ngực một lỗ.

- Chẩn đoán sau mổ là ung thư phổi không tế bào nhỏ giai đoạn I, II.

- Đầy đủ hồ sơ bệnh án đáp ứng cho nghiên cứu

\section{* Tiêu chuẩn loại trừ}

- Bệnh nhân ung thư phổi không tế bào nhỏ không được điều trị bằng phương pháp phẫu thuật nội soi lồng ngực một lố.

- Chẩn đoán sau mổ là ung thư phổi không tế bào nhỏ nhưng không phải giai đoạn I, II. đầy đủ.

Không có hồ sơ hoặc hồ sơ bệnh án không

2.2 Phương pháp: Nghiên cứu mô tả.

Qui trình phấu thuật: - Gây mê bằng ống nội khí quản 2 nòng làm xẹp phổi bên thương tổn. Bệnh nhân nằm nghiêng $90^{\circ}$ sang bên đối diện. Người mổ đứng phía trước bệnh nhân. Sử dụng dụng cụ nội soi và bộ dụng cụ phẫu thuật ít xâm lấn (Hình 1). Rạch da $3-5 \mathrm{~cm}$ qua khoang liên sườn V ngang qua đường nách trước. Tách các lớp cơ thành ngực và cắt cơ liên sườn vào khoang màng phổi. Sử dụng banh mềm (Soft retractor) bọc vết mổ.

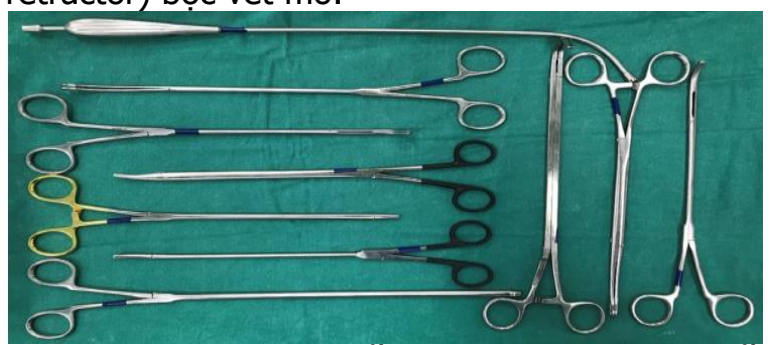

Hình 1. Dụng cụ phẫu thuật nội soi một lỗ chuyên dụng 
Dụng cụ phẫu thuật và ống kính nội soi cho đi qua trực tiếp một lỗ nhỏ trên thành ngực ở trên.

- Phẫu tích động mạch, tĩnh mạch và phế quản thùy phổi bệnh lý; cắt các thành phần này bằng dụng cụ khâu - cắt tự động (stapler). Thùy phổi bệnh lý được lấy ra khỏi lồng ngực bằng cách cho vào một túi lấy bệnh phẩm và được rút qua lỗ nhỏ trên thành ngực ở trên. Bệnh phẩm được khâu đánh dấu và gửi xét nghiệm giải phẫu bệnh lý.

- Nạo vét hạch trong trung thất: Sử dụng dao siểu âm hoặc dao ligasure trong quá trình nạo vét các nhóm hạch bạch huyết trong trung thất. Tất cả các hạch được nạo vét ra được làm giải phẫu bệnh chẩn đoán sau mỗ.

- Cầm máu và kết thúc phẫu thuật. Đặt 02 dẫn lưu màng phổi bằng ống silicon $18 \mathrm{~F}$ dưới hướng dẫn của camera, làm nở phổi trước khi đóng vết mổ.

- Chăm sóc và theo dõi sau phẫu thuât: Theo dõi các biến chứng sau phẫu thuật (chảy máu, tràn dịch màng phổi, rò khí, xẹp phổi...), chụp xquang kiểm tra và rút dẫn lưu, thu thập kết quả giải phẫu bệnh, giải thích cho bệnh nhân và gia đình về hướng theo dõi và điều trị tiếp.

Thu thập và xử lý số liệu: Số liệu được tổng hợp và thu thập trước, trong và sau mổ như lâm sàng, cận lâm sàng, kết quả giải phẫu bệnh, thời gian mổ...theo một bệnh án mẫu được thiết kế sẵn. Nhập và xử lý số liệu bằng phần mềm SPSS 20.0.

\section{KẾT QUẢ NGHIÊN CỨU}

Qua nghiên cứu và theo dõi 37 bệnh nhân, chúng tôi thu được một số kết quả như sau:

- Tuổi trung bình của các bệnh nhân trong nghiên cứu là $59,62 \pm 8,79(34-76)$.

- Số bệnh nhân nam: 21 , số bệnh nhân nữ: 16, tỷ lệ nam/ nữ: 1,31.

- Vị trí u thường gặp nhất là thùy trên phổi phải ( $15 / 37$ chiếm $40,5 \%$ )

- Kích thước u trung bình là $2,97 \mathrm{~cm}$, chủ yếu gặp ở nhóm $T 1$, chiếm $62 \%$.

Bảng 1: Đặc điểm bệnh nhân trước mổ

\begin{tabular}{|c|c|c|}
\hline Chì số & \multicolumn{2}{|c|}{ Giá trị } \\
\hline Tuối & \multicolumn{2}{|c|}{$59,62 \pm 8,79(34-76)$} \\
\hline Giới (nam/nữ) & \multicolumn{2}{|c|}{$21 / 16=1,31$} \\
\hline Biến số khác & $\mathbf{n}$ & $\mathbf{\%}$ \\
\hline Vị trí trên CT & & \\
Thùy trên phải & 15 & $40,5 \%$ \\
Thùy giữa phải & 4 & $10,8 \%$ \\
Thùy dưới phải & 5 & $13,5 \%$ \\
Thùy trên trái & 6 & $16,3 \%$ \\
Thùy dưới trái & 7 & $18,9 \%$ \\
\hline Kích thước u & & \\
\hline
\end{tabular}

\begin{tabular}{|c|c|c|}
\hline$\leq 2 \mathrm{~cm}$ & 12 & $32,4 \%$ \\
$2-3 \mathrm{~cm}$ & 11 & $29,7 \%$ \\
$3-5 \mathrm{~cm}$ & 14 & $37,9 \%$ \\
Trung bình: 2,96cm (1-5) & & \\
\hline Giai đoạn trước mố & & \\
Giai đoạn IA & 20 & $54,1 \%$ \\
Giai đoạn IB & 2 & $5,4 \%$ \\
Giai đoạn IIA & 8 & $21,6 \%$ \\
Giai đoạn IIB & 7 & $18,9 \%$ \\
\hline
\end{tabular}

Bảng 2. Kết quả phấu thuật

\begin{tabular}{|c|c|c|}
\hline \multirow[b]{2}{*}{$\begin{array}{c}\text { Thông số } \\
\text { Số thùy phối được cắt bỏ } \\
\text { Một thùy } \\
\text { Hai thùy } \\
\text { Cắt một thùy kèm cắt không } \\
\text { điển hình thùy khác }\end{array}$} & \multicolumn{2}{|c|}{ n (\%) } \\
\hline & $\begin{array}{l}31 \\
3 \\
3\end{array}$ & $\begin{array}{l}83,8 \% \\
8,1 \% \\
8,1 \%\end{array}$ \\
\hline $\begin{array}{l}\text { Thời gian phẫu thuâat (phút) } \\
\text { Thời gian phẫu thuật trung bình } \\
\text { Thời gian phẫu thuật ngắn nhất } \\
\text { Thời gian phẫu thuật dài nhất }\end{array}$ & $\begin{array}{l}150 \pm \\
22,58 \\
90 \\
195 \\
\end{array}$ & \\
\hline $\begin{array}{l}\text { Thời gian dấn lưu màng phối } \\
\text { (ngày) } \\
\text { Thời gian trung bình } \\
\text { Thời gian ngắn nhất } \\
\text { Thời gian dài nhất }\end{array}$ & $\begin{array}{c}5,59 \pm \\
1,46 \\
3 \\
9\end{array}$ & \\
\hline $\begin{array}{l}\text { Thời gian đîêu trị sau mố } \\
\text { (ngày) } \\
\text { Thời gian trung bình } \\
\text { Thời gian ngắn nhất } \\
\text { Thời gian dài nhất } \\
\end{array}$ & \begin{tabular}{|c}
$7,54 \pm$ \\
1,86 \\
4 \\
12 \\
\end{tabular} & \\
\hline $\begin{array}{c}\text { Biền chứng } \\
\text { Không có biến chứng } \\
\text { Rò khí } \\
\text { Sốt } \\
\text { Tràn dịch màng phối, rò khí } \\
\text { Viêm phổi } \\
\text { Xẹp phổi }\end{array}$ & $\begin{array}{l}29 \\
4 \\
1 \\
1 \\
1 \\
1\end{array}$ & $\begin{array}{l}78,4 \% \\
10,8 \% \\
2,7 \% \\
2,7 \% \\
2,7 \% \\
2,7 \% \\
\end{array}$ \\
\hline $\begin{array}{c}\text { Chẩn đoán giai đoạn sau mố } \\
\text { IA } \\
\text { IB } \\
\text { IIA } \\
\text { IIB }\end{array}$ & $\begin{array}{c}12 \\
6 \\
7 \\
12\end{array}$ & $\begin{array}{l}32,4 \% \\
16,3 \% \\
18,9 \% \\
32,4 \% \\
\end{array}$ \\
\hline $\begin{array}{c}\text { Giải phấu bệnh sau mố } \\
\text { Carcinoma tuyến } \\
\text { Carcinoma tuyến vảy } \\
\text { Carcinoma vảy } \\
\end{array}$ & $\begin{array}{c}34 \\
1 \\
2 \\
\end{array}$ & $\begin{array}{l}91,9 \% \\
2,7 \% \\
5,4 \%\end{array}$ \\
\hline
\end{tabular}

Trong toàn bộ bệnh nhân sau mố không có trường hợp nào có biến chứng nặng, các trường hợp biến chứng đều được điều trị nội khoa kêtt hợp với rửa khoang màng phổi, liệu pháp hô hấp thành công mà không cần mổ lại.

Bảng 3: Theo dối sau khi bệnh nhân ra viện Thời gian khám lại (tính đền 30/7/2021) (tháng) 20,15

Thời gian khám lại trung bình 


\begin{tabular}{|c|c|}
\hline $\begin{array}{l}\text { Thời gian khám lại ngắn nhất } \\
\text { Thời aian khám lai dài nhất }\end{array}$ & 55 \\
\hline $\begin{array}{l}\text { Điêu trị bố trợ sau mố } \\
\text { Không điểu trị } \\
\text { Không có chì định điều trị } \\
\text { Điều trị hóa chất } \\
\text { Điều trị hóa xa } \\
\text { Không theo dôi được }\end{array}$ & $\begin{array}{c}01 \\
06 \\
23 \\
4 \\
3\end{array}$ \\
\hline $\begin{array}{c}\text { Kết quả khám laai: } \\
\text { Số bệnh nhân ổn định } \\
\text { Số bệnh nhân có di căn } \\
\text { Số bệnh nhân đã chết vì ung thư } \\
\text { Số bệnh nhân không đi khám lai } \\
\text { Số bênh nhân không theo dôi đước }\end{array}$ & $\begin{array}{l}27 \\
02 \\
01 \\
01 \\
03\end{array}$ \\
\hline
\end{tabular}

Hầu hết các bênh nhân khám lại đều có kết quả tốt, có 2 trường hợp bệnh nhân ở giai đoạn IIA, IIB tiến triển di căn sau 1 năm, 1 trường hợp bệnh nhân giai đoạn IIB chết sau 36 tháng (2 trường hợp chết do nguyên nhân khác), 1 trường hợp không đi khám lại, các trường hợp có chỉ đinh điêu trị bổ trợ đều theo phác đồ do bác sỹ hội chẩn và chỉ định sau mổ (có 1 trường hợp bệnh nhân không điều trị mặc dù có chỉ định).

\section{BÀN LUÂ̂N}

Trong phẩu thuật nội soi một lỗ, chúng tôi sử dụng những dụng cụ chuyên dụng (Hình 1), kinh nghiệm và kỹ thuật mổ thành thạo giúp thời gian mổ được rút ngắn, Thời gian mổ trung bình $150,00 \pm 22,568$ ngắn nhất là 90 phút, dài nhất là 195 phút, tương đồng so với một số tác giả khác [6], [7]. Không có tai biến xảy ra trong mổ, không có trường hợp nào phải chuyển phương pháp mổ. Theo Rocco và cộng sự: tỷ lệ chuyển từ phẫu thuật nội soi lồng ngực một lỗ sang phương pháp khác là $3,7 \%[3]$; theo Chung và cộng sự: tỷ lệ chuyển phương pháp mổ là 35,5\% [5]

Thời gian điêuu trị sau mổ trung bình: 7,54 \pm 1,86 (4- 12ngày), Tham khảo một số nghiên cứu khác cho thây thời gian mổ nội soi ngắn hơn so với phương pháp mổ mở và hậu phẫu nhẹ nhàng hơn, ít biến chứng hơn [8],[9].

Một số nghiên cứu cũng chỉ ra rằng phẫu thuật nội soi lî̀ng ngực một lỗ so với các phương pháp phẫu thuật khác đạt hiệu quả tương đương về mặt điêu trị ung thư (cắt thuỳ phổi - nạo vét hạch), thậm chí số lượng hạch nạo vét được nhiêuu hơn so với phẫu thuật nội soi hai, ba lỗ.

Trước mổ các bệnh nhân được làm cận lâm sàng kết hợp sinh thiết u làm chẩn đoán mô bệnh học đánh giá giai đoạn bệnh (giai đoạn bệnh trước mổ) nhưng trên thực tế vần có sự chênh lệch về giai đoạn bệnh sau mổ so với trước mổ mà nguyên nhân hạn chế có thể là do các phương tiện chẩn đoán hình ảnh chưa đánh giá được chính xác tính chất của các nhóm hạch di căn, sự xâm lấn của u vào rãnh liên thùy, di căn dạng "hạt kê" vào màng phổi tạng, màng phổi thành cùng bên...Điều này cũng được đề cập tới bởi nghiên cứu của một số tác giả, theo Chao và cộng sự: Giá trị dự đoán giai đoạn đối với cắt lớp vi tính $(\mathrm{CT})$ là $68 \%$; độ nhạy trung bình, độ đặc hiệu, giá trị dự đoán dương tính, giá trị dự đoán âm tính và độ chính xác của PET/CT để phát hiện hạch di căn lần lượt là $73 \%, 91 \%, 71 \%, 90 \%$ và $86 \%$ so với $74 \%$, $73 \%, 52 \%, 88 \%, 73 \%$ đối với CT. Như vậy, đánh giá tôn thương trong mổ và lấy bệnh phẩm làm kết quả giải phẫu bệnh, vét hạch hệ thống làm chẩn đoán mô bệnh học sau mổ có vai trò quan trong trong xác định chính xác giai đoạn bệnh, từ đó định ra hướng điều trị bổ trợ tiếp theo cho bệnh nhân.

Trong nghiên cứu của chúng tôi: có $9 / 37$ (chiếm 24,3\%) bệnh nhân được sinh thiết tức thì trong mố do trước mổ có kết quả sinh thiết không phù hợp với tính chất tổn thương trên phim cắt lớp vi tính, kích thước u dưới $1 \mathrm{~cm}$ và/ hoăc do vị trí và kích thước u gây khó khăn cho sinh thiêt tổn thương trước mổ. Tất cả các trường hợp này đều được tầm soát trước mổ như một ung thư phổi. Kết quả sinh thiết tức thì phù hợp với kết quả xét nghiệm mô bệnh học thường quy sau mổ cho thây vai trò quan trọng của sinh thiết tức thì đối với phẫu thuật lồng ngực cắt thuỳ phổi nói riêng và phẫu thuật $u$ bướu nói chung.

Mặt khác, phẫu thuật nội soi lồng ngực một lỗ có ưu điểm: kích thước vết mổ ngắn, thời gian điều trị sau mổ ngắn, hậu phẫu nhẹ nhàng, ít biến chứng, và các bệnh nhân trong nghiên cứu của chúng tôi đều thấy hài lòng về mặt thẩm mỹ và về dấu hiệu đau hay dị cảm vết mổ... như khẳng định của hầu hết các tác giả trên thế giới [8],[9]. Bên cạnh đó, các nghiên cứu đều khẳng định để đạt được kết quả tốt nhất thì phẫu thuật nội soi lồng ngực một lỗ cần dụng cụ chuyền dụng, chi phí cao hơn, do thao tác qua một cổng nển phẫu thuật viên cần phải được đào tạo chuyên sâu [3], [4], việc thực hiện sinh thiết tức thì cần phải có bác sỹ giải phấu bệnh có kinh nghiệm và có chuyên môn tốt, để tránh cho bệnh nhân phải chịu thời gian gây mê lâu, phẫu thuật 2 lần do kết quả sinh thiết tức thì không đúng với kết quả xét nghiêm mô bệnh học thường quy. Phương pháp phẩu thuật này có thể triển khai rộng rãi tại các trung tâm phẩu thuật lồng ngực trong cả nước. 


\section{KẾT LUẬN}

Phẫu thuật nôi soi lồng ngực một lỗ điều trị ung thư phổi khổng tế bào nhỏ giai đoạn sớm là kỹ thuật khả thi, với ưu điểm về thẩm mỹ, ít đau sau mổ, thời gian nằm viện ngắn. Phương pháp này là một sự lựa chọn cho phẫu thuật viên và bệnh nhân trong quá trình điêu trị ung thư phổi không tế bào nhỏ.

\section{TÀl LIẸU THAM KHẢO}

1. Bray F., Ferlay J., Soerjomataram I. và công sư. (2018). Global cancer statistics 2018: GLOBOCAN estimates of incidence and mortality worldwide for 36 cancers in 185 countries. CA Cancer J Clin, 68(6), 394-424.

2. American 'Cancer Society (2007). Global cancer facts \& figures. CA Cancer J Clin, 7, 13-56.

3. Rocco G., Martucci N., La Manna C. và cộng sứ. (2013). Ten-Year Experience on 644 Patients Undergoing Single-Port (Uniportal) Video-Assisted Thoracoscopic Surgery. The Annals of Thoracic Surgery, 96(2), 434-438.

4. Fernández Prado R., Fieira Costa E., Delgado Roel M. và cộng sự. (2014). Management of complications by uniportal video-assisted thoracoscopic surgery. J Thorac Dis, 6(Suppl 6),
S669-S673.

5. Sihoe A.D.L. (2014). The evolution of minimally invasive thoracic surgery: implications for the practice of uniportal thoracoscopic surgery. J Thorac Dis, 6(Suppl 6), S604-S617.

6. Gonzalez-Rivas D., Fieira E., Delgado $M$. và cộng sự. (2013). F-105IS UNIPORTAL THORACOŚCOPIC SURGERY A FEASIBLE APPROACH FOR ADVANCED STAGES OF NONSMALL CELL LUNG CANCER?. Interactive CardioVascular and Thoracic Surgery, 17(suppl_1), S28-S28.

7. Rodgers-Fischl P.M., Martin J.T., và Saha S.P. (2017). Video-Assisted Thoracoscopic versus Open Lobectomy: Costs and Outcomes. South Med J, 110(3), 229-233.

8. Bilgi Z., Batırel H.F., Yıldızeli B. và cộng sứ (2017). No Adverse Outcomes of Video-Assisted Thoracoscopic Surgery Resection of cT2 Non-Small Cell Lung Cancer during the Learning Curve Period. Korean J Thorac Cardiovasc Surg, 50(4), 275-280.

9. Agostini P., Lugg S.T., Adams K. và cộng sự. (2017). Postoperative pulmonary complications and rehabilitation requirements following lobectomy: a propensity score matched study of patients undergoing video-assisted thoracoscopic surgery versus thoracotomyt. Interact Cardiovasc Thorac Surg, 24(6), 931-937.

\section{THỰC TRANG KHUYẾT TÂTT Ở TRẺ DƯỚI 6 TUỔI TẠI HUYÊ̂N QUỲNH PHỤ TỈNH THÁI BÌNH}

\section{Nguyễn Thị Hiền Lương*, Nguyễn Thị Kim Liên**}

\section{TÓM TẮT}

Đắt vấn đề: Phát hiện sớm và can thiệp sớm các khuyểt tât cho trẻ em là việc làm cần thiết giúp trẻ cải thiện chức năng và tạo cơ hội cho trẻ được hòa nhập cộng đồng. Mục tiêu: Mô tả thực trạng khuyết tật ở trẻ dưới 6 tuổi. Đối tượng và phương pháp nghiên cứu: Nghiên cứu cắt ngang được thực hiện trên 1524 trẻ dưới 6 tuổi trên địa bàn 3 xã thuộc huyện Quỳnh Phụ, tỉnh Thái Bình. Kết quả: Tỷ lệ bao phủ của sàng loc đat $96,3 \%$. Tỷ lê trẻ khuyết tât chiếm 1,12\% trong đó tỷ lệ trẻ nam/nữ là 1,4/1(trẻ nam $58,8 \%$, trẻ nữ $41,2 \%)$. Tỷ lê trẻ khuyết tâtt ở nhóm khó khăn về hoc và khó khăn về nhìn chiếm tỷ lệ cao nhất $(35,3 \%$ và $23,6 \%$ ). Ngoài ra, tỷ lệ trẻ khó khăn về nghe - nói, vận động lần lượt là $17,6 \%$ và $11,7 \%$. Tỷ lệ trẻ có hành vi xa la và khuyết tât khác đều bằng $5,9 \%$. Không ghi nhận trẻ khuyết tật thuộc nhóm động kinh. Kết luận: Tỷ lệ trẻ khuyết tật trên đia bàn nghiên cứu là 1,12\% trong đó tỷ lệ trẻ nam cao hơn trẻ nữ. Nhóm

*Trường Đại học Y tế công cộng

**Trướng Đai hoc Y Hà Nối

Chịu trách nhiệm chính: Nguyễn Thị Hiên Lương

Email: hienluong48@gmail.com

Ngày nhận bài: 8.7.2021

Ngày phản biên khoa hoc: 3.9.2021

Ngày duyệt bài: 10.9.2021 trẻ có khó khăn về hoc chiếm tỷ lê cao nhất trong nghiên cứu. Khuyến nghị: Nên tăng cường thực hiện sàng lọc trẻ khuyết tật trên phạm vi rộng để trẻ có cơ hội được can thiệp sớm, cải thiện chức năng.

Tư khóa: khuyết tật, trẻ em, khó khăn về học.

\section{SUMMARY}

THE SITUATION OF DISABILITIES IN

CHILDREN UNDER 6 YEARS OLD IN OUYNH PHU DISTRICT THAI BINH PROVINCE

Background: Early detection and early intervention for children with disabilities is essential to help children improve their functions and create opportunities for children to integrate into the community. Objectives: describe the situation of children with disabilities under 6 years old. Objects and research methods: The cross-sectional research were collected from 1524 children under 6 years old living in three communes of the study area. Results: The screening proportion was $96.3 \%$. The percentage of children with disabilities accounted for $1.12 \%$, of which the ratio of males to females was $1.4 / 1$ (males $58,8 \%$, females $41,2 \%$ ). The percentage of children with learning difficulties and vision difficulties accounted for the highest (35.3\% and $23.6 \%$ respectively). The proportion of children with hearing - speaking and movement difficulties were $17.6 \%$ and $11.7 \%$ respectively. $5.9 \%$ of screening 